\title{
PENGEMBANGAN LEMBAR KEGIATAN PESERTA DIDIK (LKPD) BERBASIS MODEL PEMBELAJARAN DISCOVERY LEARNING DALAM MENINGKATKAN HASIL BELAJAR EKONOMI
}

\author{
${ }^{1}$ Icha Okta Herdiana Putri, ${ }^{2}$ Ni'matush Sholikhah \\ 1'2Pendidikan Ekonomi, Fakultas Ekonomi, Universitas Negeri Surabaya \\ email : 1ichaokta97@gmail.com, ${ }^{2}$ nimatuz.fe@gmail.com
}

\begin{abstract}
Teaching material is supporting factor for students in learning, however irrelevance of teaching material used will result not achieving the learning objectives. The purpose of worksheet developer research based on discovery learning for describe the feasibility, practicality, and effectivenes of worksheet. The method used R\&D. The development model used the $4 D$ development model from Thiagarajan included define, design, develop, and disseminate. But in the step disseminate was not conducted in this study. The trial design used was Pre-Experiment Design form of One Group Pretest-Posttest. For data collection techniques using validation sheets, student questionnaire responses, and sheets of pretest and posttest. The Results showed that: 1) the result of the validation of the material experts get a percentage of $84.8 \%$, learning experts by $75 \%$, graphic experts by $77.14 \%$, and evaluation experts by $99.73 \%$. The average validation results get a percentage of $84.16 \%$ included in the very feasible criteria; 2) student responses get a percentage of $89.71 \%$ included in the very feasible criteria; 3) student learning outcomes get an n-gain of 0.72 included in the high criteria. Based on the results it can be concluded that worksheet developed is feasible, effective, and practically used as theaching material.

Keyword: discovery learning, employment, worksheet
\end{abstract}

\begin{abstract}
ABSTRAK
Bahan ajar merupakan faktor penunjang peserta didik dalam pembelajaran, namun tidak relevannya bahan ajar yang diberikan akan mengakibatkan tidak tercapainya tujuan dari pembelajaran. Tujuan dari penelitian pengembang LKPD berbasis model pembelajaran discovery learning untuk mendeskripsikan kelayakan, kepraktisan, dan keefektifan dari LKPD. Metode yang dijadikan yaitu R\&D. Untuk model pengembangan yang dijadikan yakni model pengembangan 4-D dari Thiagarajan meliputi define, design, develop, dan disseminate. Namun tahap disseminate tidak dilaksanakan. Desain ujicoba yang dibuat yaitu Pre-Experiment Design berupa One Group Pretest-Posttest. Untuk teknik pengumpulan data yang digunakan yaitu lembar validasi, angket respon peserta didik, dan lembar pretest dan posttest. Hasil penelitian menyatakan bahwa 1) hasil validasi ahli materi memperoleh persentase sebanyak $84,8 \%$, ahli pembelajaran sebanyak $75 \%$, ahli kegrafikan sebanyak $77,14 \%$, dan ahli evaluasi sebanyak 99, 73\%. Rata-rata hasil validasi mendapatkan persentase sebanyak $84,16 \%$ termasuk kategori sangat layak; 2) respon peserta didik mendapatkan persentase sebesar $89,71 \%$ termasuk kategori sangat layak; dan 3) hasil belajar peserta didik mendapatkan n-gain sebanyak 0,72 termasuk pada kriteria tinggi. Berdasarkan hasil tersebut disimpulkan bahwa LKPD yang dikembangkan layak, efektif, dan praktis sebagai bahan ajar.

Kata Kunci: discovery learning, ketenagakerjaan, LKPD
\end{abstract}

\section{PENDAHULUAN}

Tujuan utama dari pendidikan dalam sebuah instansi persekolahan yaitu mampu mengembangankan kapasitas intelektual peserta didik yang dilakukan secara terprogram dan koordinatif. Menurut Tambunan (2016) pendidikan merupakan tanggungjawab bersama, maka dibutuhkan kerjasama dengan beberapa pihak. Pihak yang dibutuhkan seperti penentu kebijakan, pihak sekolah, dan masyarakat luas. Masalah dalam bidang pendidikan 
yang dihadapi Indonesia sangat beragam dan kompleks. Salah satu contoh dari masalah dalam bidang pendidikan yaitu krisisnya paradigma yang digunakan. Sebagai contoh dari kesenjangan ini peserta didik pada semua jejang pendidikan diharuskan untuk menguasai semua informasi. Hal ini mengakibatkan peserta didik hanya menggunakan pengetahuan jangka pendeknya, sedangkan kehidupan dimasa depan peserta didik dituntut mampu memecahkan persoalan yang inovatif dan kreatif.

Sebagai pilar dasar dari lembaga pendidikan di Indonesia, satuan pendidikan Sekolah Menengah Atas juga tidak terbebas dari masalah, salah satunya yaitu bahan ajar yang digunakan. Dengan menggunakan bahan dalam pembelajaran bermanfaat untuk mempermudah guru dan peserta didik untuk saling berkomunikasi dan berinteraksi. Dalam dunia pendidikan, perlu adanya bahan ajar yang berfungsi untuk mengarahkan dan sumber referensi bagi guru maupun peserta didik demi tercapinya kompetensi. Salah satu contoh bahan ajar yaitu Lembar Kegiatan Peserta didik. LKPD berupa bentuk naskah tulisan yang mampu menolong peserta didik agar proses belajarnya dapat terarah (Fadliana, Redjeki, \& Nuhayati ,2013). LKPD digunakan dalam menunjang proses belajar dikelas dalam menyediakan materi pembelajaran. Peran LKPD ialah agar mencapai tujuan dari pembelajaran. LKPD termasuk kedalam bahan ajar yang digunakan agar dapat menghasilkan suatu pembelajaran yang berhasil dan juga praktis (Herman \& Salim, 2015).

Berdasarkan pengamatan SMAN 1 Cerme merupakan salah satu sekolah Negeri di Gresik dimana dalam proses pembelajarannya menerapkan Kurikulum 2013. Dengan menerapkan kurikulum 2013 maka akan mempengaruhi cara guru dalam mendidik dan menyusun perangkat pembelajaran serta menentukan bahan ajar yang akan diberikan. Untuk mendukung proses pembelajaran dikelas bahan ajar yang diberikan yakni Buku Paket dan Lembar Kegiatan Peserta Didik (LKPD). Untuk buku paket ekonomi jumlahnya sangat sedikit sehingga setiap buku harus digunakan dengan teman sebangkunya. Selain itu, materinya juga kurang lengkap, terdapat beberapa sub bab materi yang tidak disajikan dalam buku paket tersebut. Materi yang tidak disajikan yaitu pada materi ketenagakerjaan. Pada subbab pengangguran tidak dijelaskan faktor-faktor penyebab pengangguran. Sedangkan materi tersebut ada pada RPP yang digunakan oleh guru ekonomi. Latihanlatihan soal untuk melatih kemampuan berpikir kritis pun kurang, sebab latihan soal yang ada pada buku paket tersebut tergolong level kognitif C1 sampai C4 saja. Sedangkan untuk LKPD yang dibuat ialah LKPD yang dibeli dari penerbit.

LKPD berupa bentuk naskah tulisan yang mampu menolong peserta didik agar proses belajarnya dapat terarah (Fadliana, Redjeki, \& Nuhayati ,2013). Penggunaan LKPD dalam menunjang proses belajar mengajar dikelas juga mempermudah guru dalam membimbing peserta didik agar mampu mendapatkan konsep-konsep dalam menempuh kegiatannya secara mandiri. Maka dari itu dengan menyusun desain perangkat LKPD yang baik akan mendorong peserta didik berperan aktif saat pembelajaran dikelas. LKPD yang digunakan pada mata pelajaran ekonomi tersebut sebenarnya sudah bagus. Namun dari wawancara bersama beberapa peserta didik saat pra penelitian, sebagain besar dari peserta didik merasakan kesusahan saat menyelesaikan latihan soal pada LKPD tersebut. Hal itu terjadi karena peserta didik kurang memahami materi yang dijelaskan guru. Dimana peserta didik mengerjakan soal-soal yang terdapat di LKPD setelah mendengarkan penjelasan dari guru tanpa melaksanakan suatu kegiatan sebagai usaha dalam menolong peserta didik menguasai materi dan melatih kemampuan berpikir kritis. Sesuai kururikulum 2013 yang diterapkan oleh sekolah, hal tersebut menuntut peserta didik agar aktif mengkonstruk materi. Peserta didik juga merasa LKPD yang digunakan tersebut kurang bervariasi seperti model yang digunakan sama pada semua materi dan kurang menarik karena isi pada LKPD tidak berwarna. Materi yang ada pada LKPD tersebut sangat sedikit dan hampir sama seperti rangkuman dari suatu materi. Latihan soalnya pun sangat terbatas, dimana latihan soal dalam LKPD penting bagi peserta didik dalam melatih kemampuannya terhadap pemahaman suatu materi. Sehingga, akan berdampak pada hasil belajar peserta didik yang tidak sampai KKM. 
Menurut Prayitno (2013) KKM ialah sebagai acuan dalam menetapkan peserta didik secara minimal dalam mencapai persyaratan suatu materi pada mapel tertentu. Di SMAN 1 Cerme KKM yang ditetapkan pihak sekolah untuk kelas XI pada mata pelajaran ekonomi yakni 75. Berdasarkan data dari hasil pra penelitian didapat dari guru ekonomi kelas XI mengutarakan bahwa dari tiga kelas XI IPS hasil belajar peserta didik yang paling sedikit ialah XI IPS 3. Selain itu, banyak peserta didik nilainya tidak memenuhi KKM yaitu sebesar 28 peserta didik, dimana jumlah dari kelas XI IPS 3 sebanyak 36 . Berikut ini grafik hasil belajar peserta didik.

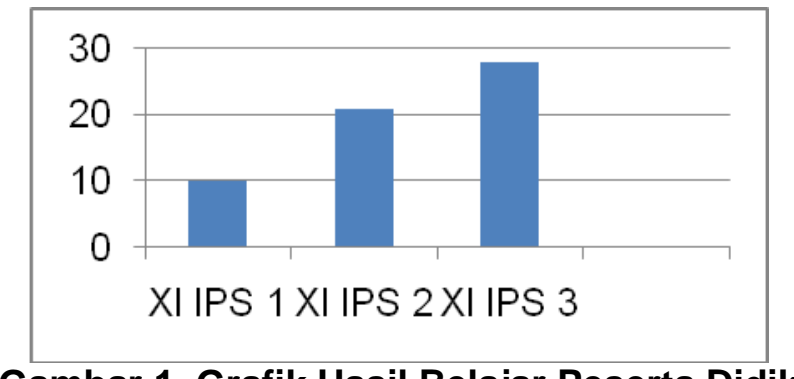

Gambar 1. Grafik Hasil Belajar Peserta Didik

Sumber: Data diolah peneliti (2020)

Hasil wawancara bersama guru ekonomi yang dilakukan saat studi pendahuluan juga menyatakan bahwa dari segi keaktifan peserta didik saat pembelajaran berlangsung kelas XI IPS 3 merupakan kelas yang paling lambat dan tertinggal dari kelas yang lain. Kelas XI IPS 3 juga kurang aktif dalam mencari informasi dari sumber lain dan kelas XI IPS 3 sekadar menggantungkan materi yang diajarkan guru saat proses belajar mengajar dikelas. Selain itu, mereka hanya mengandalkan buku pegangan peserta didik yang dipinjami oleh pihak sekolah dimana jumlahnya sangat sedikit. Hasil studi pendahuluan dengan membagikan angket kepada peserta didik kelas XI IPS 3 menyatakan bahwa sebanyak $61 \%$ peserta didik merasa kesulitan dimateri ketenagakerjaan dan sisanya dimateri lainnya.

Hasil pemberian angket pada peserta didik saat studi pendahuluan juga menyatakan bahwa mereka menginginkan pengembangan LKPD. Pengembangan LKPD dalam menunjang proses pembelajaran ekonomi dikelas diharapkan mampu mewujudkan peserta didik untuk semakin giat saat pembelajaran berlangsung dan mampu menaikkan hasil belajarnya. Salah satu keuntungan dengan adanya LKPD bagi guru yaitu mempermudah guru melaksanakan pembelajaran. Sedangkan untuk peserta didik mampu belajar dengan mandiri agar dapat memahami dan menjelaskan suatu tugas tertulis. Rahayu \& Budiyono (2018) mengungkapkan bahwa penggunaan LKPD mampu menarik peserta didik untuk turut aktif pada materi yang dibahas. Dengan terciptanya pembelajaran yang aktif, maka peserta didik mendapatkan pengalaman secara langsung dan tidak terbatas dengan pengetahuan belaka. Penggunaan LKPD dalam menunjang proses belajar mengajar dikelas juga mempermudah guru dalam membimbing peserta didik agar mampu mendapatkan konsepkonsep dalam menempuh kegiatannya secara mandiri. Maka dari itu dengan menyusun desain perangkat LKPD yang baik akan mendorong peserta didik berperan lebih aktif saat pembelajaran dikelas.

Mempertimbangan kondisi yang terjadi, maka sangat diperlukan untuk mengembangan LKPD yang mampu menarik peserta didik, berpusat pada peserta didik dan berpijak pada pemahaman sesuai tujuan dari penerapan Kurikulum 2013 ysng diterapkan oleh sekolah. Oleh karena itu, untuk menarik minat peserta didik dan pembelajaran dikelas terasa bermakna bagi peserta didik maka dapat menggunakan model discovery learning. Penggunan LKPD berbasis discoveri learning dalam menunjang pembelajaran dikelas juga mampu meningkatkan keterampilan dan proses koginitif peserta didik dalam memahami materi Nua, Wahdah, \& Mahfud ,2018). 
Discovery learning ialah model pembelajaran yang menjadikan peserta didik menjadi pusat belajar yang aktif. Menurut Cahyo (2013) mengungkapkan bahwa discovery learning ialah suatu model yang yang merancang proses pembelajaran dengan agar peserta didik mendapat pengetahuan yang sebelumnya tidak tahu dan bukan dari penjelasan dari guru tetapi menemukan secara mandiri. Model pembelajaran discovery learning ialah komponen dari penerapan pendidikan dengan melalui langkah-langkah pembelajaran yang menjadi peserta didik aktif saat belajar, dan mengarahkan peserta didik untuk mandiri dan reflektif. Prosedur aplikasi pada model pembelajaran discovery learning melalui enam tahapan yakni stimulasi atau pemberian rangsang, pernyataan atau identifikasi masalah, pengumpulan data, pengelolahan data, pembuktian, dan menarik kesimpulan (Syah, 2004).

Penelitian dari Sannah, Kadaritna, \& Tania (2015) membuktikan bahwa penelitian pengembangan LKPD dengan model discovery learning pada materi teori atom bohr yang memperoleh hasil bahwa LKPD yang dikembangkan sudah memenuhi syarat layak, praktis, dan juga efektif untuk digunakan sebagai bahan ajar. Adapaun penelitian dari Astra, Nasbey, \& Muharrahmah (2015) yang mebuktikan bahwa LKPD berbasis model pembelajaran discovery learning layak dipakai dan dapat disebar luaskan sebagai bahan ajar untuk menunjang proses pembelajaran dikelas $X$ pada mata pelajaran Fisika. Selain itu, penelitian dari Nurisalfah, Ritna, \& Tania (2015) yang mengembangkan LKPD dengan model discovery learning pada materi teori atom mekanika kuantum juga mendapatkan hasil validasi yang sangat tinggi, respon guru dan respon peserta didik memenuhi syarat layak, dan hasil belajar peserta didik juga memenuhi syarat efektif.

Penelitan ini memiliki tujuan untuk mendeskripsikan kelayakan LKPD berbasis model pembelajaran discovery learning pada materi ketenagakerjaan, mendeskripsikan kepraktisan LKPD berbasis model pembelajaran discovery learning pada materi ketenagakerjaan, dan mendeskripsikan keefektifan LKPD berbasis model pembelajaran discovery learning pada materi ketenagakerjaan. Berdasarkan uraian tersebut, maka peneliti tertarik melakukan penelitian dengan judul "Pengembangan Lembar Kegiatan Peserta Didik (LKPD) Berbasis Model Pembelajaran Discovery Learning Pada Materi Ketenagakerjaan".

\section{LANDASAN TEORI \\ Bahan Ajar}

Semua bentuk komponen berupa perlengkapan, informasi maupun bacaan yang dirancang secara terstruktur dan sesuai keterampilan yang harus dikuasai oleh peserta didik serta dapat membantu guru menjalankan proses belajar agar mencapai tujuan dari pembelajaran ialah yang dimaksud bahan ajar (Prastowo, 2014). Sedangkan menurut Mudlofar (2012) semua bentuk komponen yang disusun sebagai upaya untuk mempermudah guru saat melakukan proses belajar mengajar ialah yang dimaksud dari bahan ajar. Pada dunia pendidikan, perlu adanya bahan ajar yang berfungsi untuk mengarahkan dan sumber referensi bagi guru maupun peserta didik demi tercapainya kompentensi. Dengan menggunakan bahan ajar mampu digunakan sebagai alat evaluasi capaian hasil belajar dan merupakan bagian terpenting pada proses pembelajaran.

\section{Lembar Kegiatan Peserta Didik}

Menurut Majid (2012) Lembar Kegiatan Peserta Didik ialah tugas yang harus dikerjakan oleh peserta didik yang penyajiannya berupa lembaran-lembaran. Sedangkan menurut Trianto (2017) dalam LKPD terdapat kumpulan kegiatan mendasar yang digunakan untuk memaksimalkan pemahaman, tujuannya adalah untuk membentuk kompetensi dasar sesuai dengan perolehan hasil belajar peserta didik. Dengan menggunakan LKPD memberi pengaruh begitu besar saat proses pembelajaran karena penggunaan LKPD dapat mebantu peserta didik meningkatkan pemahamannya terhadap suatu materi. Sehingga akan berpengaruh juga terhadap peningkatkan hasil belajar peserta didik

\section{Model Pembelajaran Discovery learning}

Proses pembelajaran yang disusun supaya peserta didik mampu mengorganisasi materi yang sedang diajarkan oleh guru secara mandiri bukan memperoleh bentuk akhirnya merupakan pengertian dari model pembelajaran discovery learning (Kurniasih \& Sani ,2014). 
Suatu kategori atau konsep yang dibentuk agar peserta didik dapat giat saat menyelidiki dan mendapatkan suatu konsep secara mandiri dengan harapan hasil akhir yang diperoleh setiap peserta didik dapat tahan lama dalam ingatan merupakan pengertian dari model discovery learning Hosnan (2014). Penggunaan model discovery learning dapat menghasilkan pembelajaran yang aktif dan kreatif. Dengan semakin aktif serta kreatifnya peserta didik dapat membantu peserta didik dalam memahami materi. Sehingga hal tersebut akan berpengaruh terhadap peningkatkan pemahaman peserta didik terhadap materi dan juga hasil belajar peserta didik.

\section{Respon Peserta Didik}

Pada penelitian pengembangan suatu model yang dikembangkan dapat dikatakan praktis apabila sudah dinilai oleh para ahli dan dinyatakan dalam kategori baik dan dapat diuji cobakan di lapangan (Rochmad ,2012). Dalam penelitian aspek kepraktisan diukur dari respon peserta didik. Menurut Ahmadi (2009) respon merupakan hasil yang diperoleh seseorang dari kegiatan mengamati suatu hal yang tersimpan dalam ingatannya.

\section{Hasil Belajar}

Mengetahui tingkat keefektifan dapat dilihat hasil akhir ataupun penghargaan yang telah diperoleh seseorang setelah mempelajari suatu hal dan berkeinginan untuk terus mempelajarinya (Nieveen dalam Rochmad, 2012). Pada penelitian ini untuk mengukur aspek keefektifan dilihat dari hasil belajar peserta didik. Menurut Hamalik (2017) hasil belajar ialah pengukuran yang dinilai dari bentuk sikap, pengetahuan, dan juga keterampilan dari hasil transformasi seseorang yang dapat diamati.

\section{METODOLOGI}

Research and Development (R\&D) ialah penelitian yang digunakan oleh peneliti dalam melakukan penelitian ini dan model pengembangan yang digunakan ialah model 4-D dari Thiagarajan. Tahapan model 4-D meliputi Define, Design, Develop, dan Disseminate, namun tahap disseminate tidak dilaksanakan. Berikut gambaran prosedur penelitian yang digunakan:

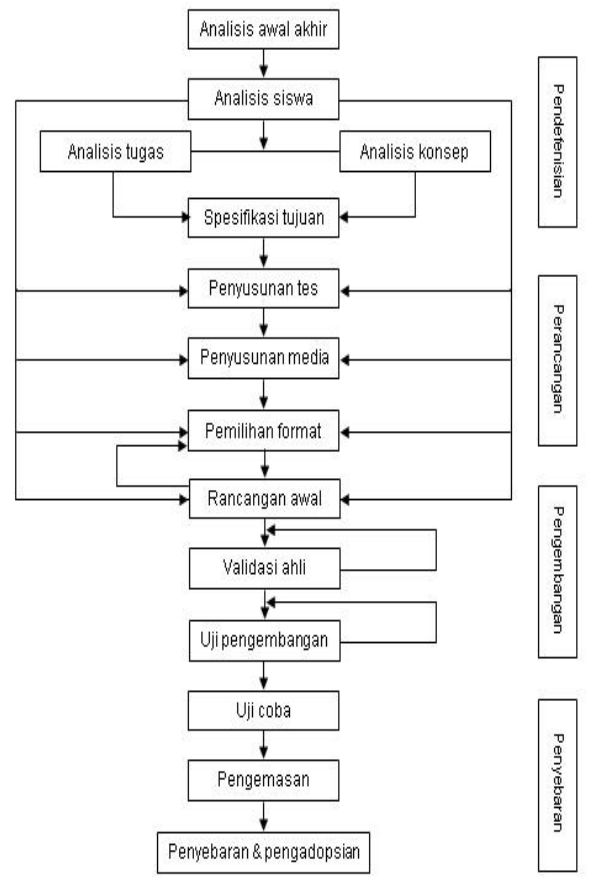

\section{Gambar 2.Prosedur Penelitian}

Sumber: Trianto (2014)

Desain ujicoba pada penelitian ini yaitu Pre-Experiment dengan bentuk One Group PretestPosttest Design. Pada penelitian pengembangan ini bertujuan untuk mendeskripsikan kelayakan dari LKPD yang diukur dari validasi para ahli, untuk mendeskripsikan keprakitsan 
dari LKPD yang diukur dari respon peserta didik, dan untuk mendeskripsikan keefektifan dari LKPD yang diukur dari hasil belajar peserta didik.

Pertama-tama ditahap pendefinisian dilakukan analisis awal untuk mengetahui informasi tentang masalah yang ada disekolah. Langkah selanjutnya yaitu analisis peserta didik dengan tujuan mengamati karaktristik peserta didik. Karakteristik peserta didik yang dilihat melalui tingkat pemikiran dan pengetahuan, tingkat usia serta melihat pengalaman dan wawasan yang telah diperoleh peserta didik dalam memahami suatu materi. Selanjutnya analisis konsep, dalam langkah ini yang dilakukan yaitu melihat konsep utama yang akan diajarkan serta merancang konsep secara tersktuktur. Kemudian dilanjutkan dengan analisis tugas yang memiliki tujuan untuk memilih isi dalam satuan pembelajaran yang meliputi bagian isi materi yang disesuaikan dengan KD dan indikator serta memilih tugas untuk diselesaikan oleh peserta didik yaitu menyelesaikan kegiatan yang ada pada LKPD. Untuk langkah terakhir yang dilakukan yaitu spesifikasi tujuan, dalam spesifikasi tujuan menuliskan apa saja tujuan yang diharapkan dari pelaksanaan pembelajaran.

Selanjutnya pada tahap kedua yakni tahap perancangan. Dengan tujuan mempersiapkan prototype pengembangan berupa LKPD melalui empat langkah. Langkah pertama yakni penyusunan tes, pada langkah ini penggabungan tahap define dan design akan menjadi langkah awal dalam penyusunan tes. Langkah selanjutnya yakni pemilihan media yang dignakan untuk menentukan media pembelajaran yang disesuaikan dengan materi, tujuan pembelajaran, dan kebutuhan dari peserta didik. Kemudian dilanjutkan dengan menentukan format, dalam menentukan format memiliki tujuan untuk menentukan format yang disesuaikan dengan materi yang akan dikembangkan dalam LKPD. Langkah terakhir yaitu rancangan awal, pada tahap ini telah dibuat LKPD yang selanjutnya akan ditelaah oleh beberapa pakar ahli untuk diberikan saran dan masukan terhadap produk yang ditelaah tersebut.

Tahap terakhir yang dilakukan yaitu tahap pengembangan, tahap ini meliputi telaah LKPD yang selanjutnya hasilnya direvisi oleh peneliti, kemudian validasi yang dilakukan para ahli, dan ujicoba. Setelah prototype 1 LKPD diselesaikan, LKPD ditelaah oleh beberapa ahli untuk diberikan masukan dan juga saran sebagai upaya penyempurnaan LKPD. Kemudian LKPD direvisi berdasarkan saran yang diberikan oleh para ahli yang akhirnya menjadi prototype 2 LKPD. Setelah prototype 2 selesai, para ahli melakukan validasi untuk menegatahui kelayakan dari LKPD berbasis discovery learning. Setelah LKPD dikatakan layak oleh para ahli maka LKPD dapat diuji cobakan pada peserta didik kelas XI IPS 3 SMA Negeri 1 Cerme sebanyak 36.

Analisis kualitatif dan kuantitatif yanga akan dibuat dalam menganalisis data yang didapat dari penelitian pengembang ini yang meliputi:

1. Lembar Telaah

Telaah dilakukan oleh beberapa ahli yakni ahli materi, kegrafikan, pembelajaran, dan evaluasi. Prototype 1 ditelaah oleh para ahli tersebut kemudian hasilnya akan dianalisis untuk memperbaiki prototype 1.

2. Lembar Validasi

Validasi dilakukan oleh para ahlidiantaranya ahli materi, kegrafikan, pembelajaran, dan evaluasi. Dari hasil validasi akan diperoleh data dalam bentuk skor pada setiap aspek dari pengisian angket. Hasil dari validasi yang didapatkan akan dianalisis secara deskriptif kuantitaif. Hasil analisis tersebut berupa persentase dari setiap komponen dari hasil angket. Berikut ini tabel kriteria penilaian validasi yang dilakukan oleh para ahli:

Tabel 1. Kriteria Penilaian Lembar Validasi Berdasarkan Skala Likert

\begin{tabular}{|c|c|}
\hline Skor & Kriteria \\
\hline 5 & Sangat Layak \\
\hline 4 & Layak \\
\hline 3 & Cukup Layak \\
\hline 2 & Tidak Layak \\
\hline 1 & Sangat Tidak Layak \\
\hline
\end{tabular}

Sumber : Riduwan (2013) 
Berikut rumus yang digunakan dalam menganalisis hasil lembar validasi LKPD:

Berikut tabel kriteria skor:

$$
\text { Nilai Kelayakan LKPD }=\frac{\text { Jumlah Skor Total }}{\text { Skor Kriteria }} \times 100 \%
$$

Tabel 2. Kriteria Skor Kelayakan Para Ahli

3. Respon Peserta Didik

\begin{tabular}{|c|c|}
\hline Skor & Kriteria \\
\hline $81-100$ & Sangat Layak \\
\hline $61-80$ & Layakk \\
\hline $41-60$ & Cukup Layak \\
\hline $21-40$ & Tidak Layak \\
\hline $0-20$ & Sangat Tidak Layak \\
\hline
\end{tabular}

Sumber: Riduwan (2013)

Hasil angket respon peserta didik dibuat untuk mendeskripsikan kepraktisan dari pengembangan LKPD melalui tanggapan dari peserta didik setelah LKPD diujicobakan. Angket ini berisi respon dari peserta didik mengenai penggunaaan pengembangan LKPD. Berikut ini tabel kriteria penilaian respon peserta didik:

\section{Tabel 3. Kriteria Penilaian Angket Respon PesertaDidik Berdasarkan Skala} Guttman

\begin{tabular}{|c|c|}
\hline Skorr & Kriteriaa \\
\hline 1 & Ya \\
\hline 0 & Tidak \\
\hline
\end{tabular}

Berikut rumus untuk menganalisis respon peserta didik:

$$
\text { Jumlah Respon Peserta Didik }=\frac{\sum \text { Siswa yang menjawab " }{ }^{~} a^{\mathrm{D}}}{\text { Siswa keseluruhan }} \times 100 \%
$$

Tabel 4. Kriteria Skor Interpretasi Respon Peserta Didik

\begin{tabular}{|c|c|}
\hline Skor & Kriteria \\
\hline $81-100$ & Sangat Layak \\
\hline $61-80$ & Layakk \\
\hline $41-60$ & Cukup Layak \\
\hline $21-40$ & Tidak Layak \\
\hline $0-20$ & Sangat Tidak Layak \\
\hline \multicolumn{2}{|c|}{ Sumber: Riduwan (2013) }
\end{tabular}

4. Peningkatan Hasil Belajar

Data dari hasil belajar belajar peserta didik dibuat untuk mendeskripsikan keefektifan dari pengembangan LKPD. Untuk mengetahui hasil belajar maka diberikan pretest dan posttest saat ujicoba lapangan. Hasil pretest dan posttest dianalisis dengan uji N-gain. Berikut ini rumus perhitungan N-Gain:

$$
\mathrm{g}=\frac{\text { skor posttest }- \text { skor pretest }}{\text { skor maksimal }- \text { skor pretest }}
$$

Tabel 5. Kriteria Uji N-Gain

\begin{tabular}{|c|c|}
\hline Skor & Kriteria \\
\hline $\mathrm{g}>0,70$ & Tnggi \\
\hline $0,3 \leq \mathrm{g} \leq 0,70$ & Sedang \\
\hline $\mathrm{g}<0,30$ & Rendah \\
\hline
\end{tabular}

Selesai hasil pretest dan posttest diolah dengan rumus uji $\mathrm{N}$-gain, apabila $70 \%$ hasilnya termasuk kedalam kriteria sedang dan tinggi maka LKPD tersebut dapat dikatakan efektif serta LKPD dapat digunakan sebagai bahan ajar. 


\section{HASIL DAN PEMBAHASAN \\ Hasil}

Pada tahap pendefinisian pertama-tama dilakukan analisis awal yang bertujuan untuk mendapatkan informasi mengenai masalah yang terdapat pada saat proses belajar di SMAN 1 Cerme. Hasil wawancara bersama guru ekonomi di SMA Negeri 1 Cerme saat peneliti melakukan studi pendahuluan mendapati bahwa kurikulum yang diterapkan sekolah dalam kegiatan belajar mengajar yaitu K-13.

Tabel 6. KD Materi dan Tujuan Pembelajaran

\begin{tabular}{|c|c|}
\hline Kompetensi Dasar & Tujuan Pembelajaran \\
\hline \multirow{10}{*}{$\begin{array}{l}\text { 3.3 Permasalahan } \\
\text { ketenagakerjaan } \\
\text { dalam pembangunan } \\
\text { ekonomi }\end{array}$} & $\begin{array}{l}\text { Peserta didik mampu mendeskripsikan pengertian tenaga } \\
\text { kerja, angkatan kerja, dan kesempatan kerja }\end{array}$ \\
\hline & $\begin{array}{l}\text { Peserta didik mampu mengidentifikasi jenis-jenis tenaga } \\
\text { kerja }\end{array}$ \\
\hline & $\begin{array}{l}\text { Peserta didik mampu menganalisis permasalahan } \\
\text { ketenagakerjaan di Indonesia }\end{array}$ \\
\hline & $\begin{array}{l}\text { Peserta didik mampu menjelaskan upaya meningkatkan } \\
\text { kualitas tenaga kerja }\end{array}$ \\
\hline & Peserta didik mampu mengidentifikasi sistem upah \\
\hline & $\begin{array}{l}\text { Peserta didik mampu mendeskripsikan pengertian } \\
\text { pengangguran }\end{array}$ \\
\hline & $\begin{array}{l}\text { Peserta didik mampu menjelaskan sebab-sebab } \\
\text { pengangguran }\end{array}$ \\
\hline & $\begin{array}{l}\text { Peserta didik mampu mengindenftikasi jenis-jenis } \\
\text { pengangguran }\end{array}$ \\
\hline & Peserta didik mampu menjelaskan dampak pengangguran \\
\hline & $\begin{array}{l}\text { Peserta didik mampu menganalisis cara mengatasi } \\
\text { pengangguran }\end{array}$ \\
\hline
\end{tabular}

Sumber: Diolah oleh peneliti (2020)

Saat pembelajaran dikelas guru memakai buku paket dan LKPD, namun menurut guru mata pelajaran ekonomi LKPD yang digunakan tersebut masih umum. Karena dalam LKPD kurang mencantumkan langkah-langkah pelaksanaan tugas yang sesuai dengan kurikulum 2013. Latihan soal yang ada pada LKPD juga sangat sedikit jumlahnya, sehingga peserta didik kurang terlatih dalam mengerjakan soal. Langkah selanjutnya yaitu analisis peserta didik, yang dimaksudkan untuk mengamati ciri-ciri peserta didik. Karakteristik dilihat berupa tingkat pemikiran dan pengetahuan, tingkat usia serta pengalaman dan wawasan yang diperoleh peserta didik dalam mencerna materi ketenagakerjaan. LKPD ini diuji cobakan pada peserta didik kelas XI SMAN 1 Cerme sebanyak 36 yang berada di usia 17-18 tahun. Kemudian dilanjutkan dengan analisis konsep, analisis konsep merupakan hasil analisis dari materi atau KD yang digunakan kemudian dijabarkan dalam bentuk peta konsep. Langkah selanjutnya yaitu analisis tugas yang terdapat dalam LKPD yang mencakup materi yang akan dijabarkan dan berbasis model pembelajaran discovery learning. Kemudian langkah terakhir yaitu spesifikasi tujuan, dalam spesifikasi tujuan disesuai dengan materi ketenagakerjaan.

Tahap kedua yaitu tahap perencanaan, pada tahap perencanaan (Design) disusun prototype supaya memudahkan peneliti dalam merancang pengembangan LKPD yang disesuaikan panduan pembuatan LKPD. Langkah pertama yaitu penyusunan tes, pada langkah ini bermaksudkan untuk mencari tahu sedalam apa pemahaman peserta didik pada materi dilakukan penyusunan soal pretest dan posttest. Kemudian juga disusun butir soal dalam LKPD yang harus diselesaikan secara mandiri atau kelompok. Dalam soal tersebut berisikan materi yang sesuai dengan KD. Untuk langkah selanjutnya yakni pemilihan media, yang dijadikan pada pada LKPD ini berupa ilustrasi gambar dimana peserta didik harus mengalami dan merumuskan beberapa pertanyaan mengenai ilustrasi tersebut. Media 
tersebut dijadikan untuk memudahkan peserta didik mendapatkan konsep secara mandiri melalui hasil pengamatannya serta pencarian informasi dari beberapa sumber.selain itu agar mempermudah peserta didik mencerna materi maka disajikan ilustrasi gambar yang disesuaikan materi. Langkah terakhir yaitu menentukan format, dalam menentukan format dibagi menjadi empat langkah yaitu: 1) menetukan jenis LKPD, LKPD dirancang dalam mencapai KD 3.3 mengenai permasalahan ketenagakerjaan dalam pembangunan ekonomi dengan menggunakan discovery learning sebagi model pembelajarannya. Penggunaan model discovery learning untuk menjadikan peserta didik sebagai pusat belajar yang aktif; 2) menentukan judul LKPD, judul LKPD dirancang berdasarkan model pembelajaran yang dijadikan pada pengembangan LKPD yaitu model discovery learning. Maka judul yang digunakan adalah "Lembar Kegiatan Peserta Didik Berbasis Model Pembelajaran Discovery Laerning"; 3) penyusunan materi, materi yang disajikan pada pengembangan LKPD yaitu materi ketenagakerjaan; 4) rancangan awal, pada rancangan awal desain LKPD disusun oleh peneliti dengan menghasilkan prototype 1.

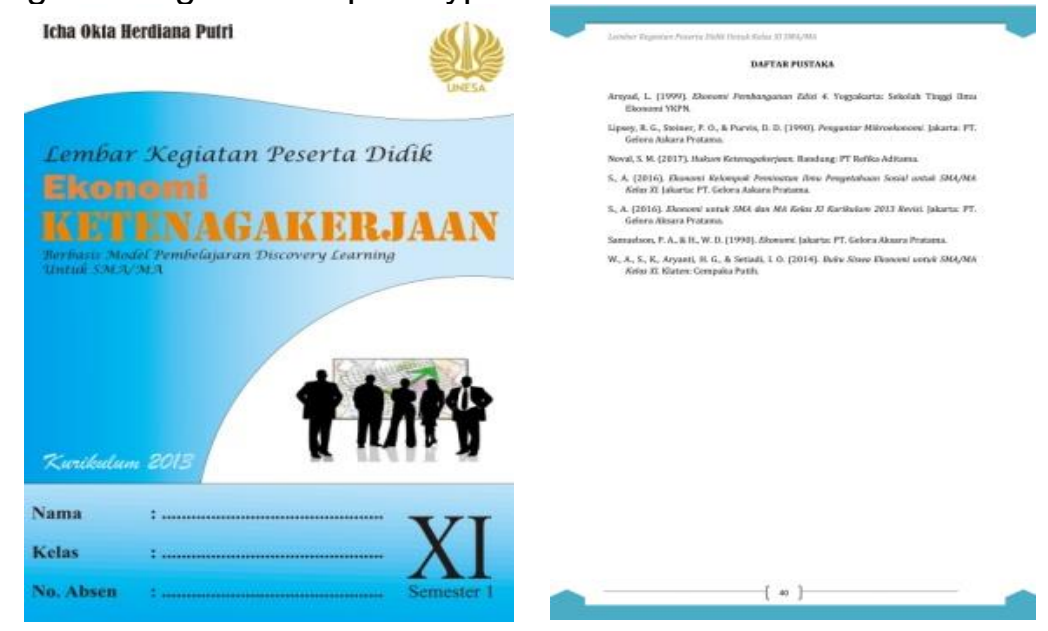

Gambar 3. Cover dan Daftar Pustaka LKPD

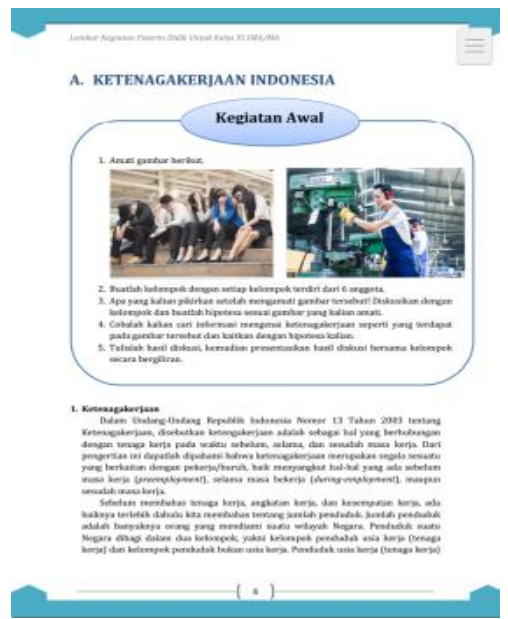

Gambar 4. Lembar Tugas dan Materi Sebelum Revisi

Tahap yang terakhir yaitu tahap pengembangan (develop). Tahap ini melalui tiga langkah yaitu telaah dan revisi, validasi, dan uji coba. Setelah prototype satu LKPD selesai, LKPD akan ditelaah oleh para ahli untuk diberi masukan dan saran dalam penyempurnaan LKPD sebelum diuji cobakan kepada peserta didik. 
Oikos: Jurnal Kajian Pendidikan Ekonomi dan IImu Ekonomi, ISSN Online: 2549-2284

Volume IV Nomor 2, Juli 2020

\section{Tabel 7. Hasil Telaah Para Ahli}

\begin{tabular}{|l|l|}
\hline \multicolumn{1}{|c|}{ Validator } & \multicolumn{1}{c|}{ Keterangan } \\
\hline Ahli Materi & $\begin{array}{l}\text { - Bagian isi materi angkatan kerja harus disesuaikan dengan } \\
\text { data BPS } \\
\text { - Beberapa data terkini mengenai pengangguran } \\
\text { - Tingkat lulusan penduduk diupdate minimal ditahun } 2019 \\
\text { - Beberapa kalimat yang menimbulkan ketidaktepatan dalam } \\
\text { LKPD }\end{array}$ \\
\hline Ahli Pembelajaran & $\begin{array}{l}\text { - Langkah-langkah model pembelajaran discovery learning perlu } \\
\text { ditekankan }\end{array}$ \\
\hline Ahli Kegrafikan & $\begin{array}{l}\text { - Pilih gambar sesuai fungsinya dan perhatikan prinsip-prinsip } \\
\text { penggunaannya } \\
\text { - Perhatikan aturan atribut pada gambar berlisensi publik }\end{array}$ \\
\hline Ahli Evaluasi & $\begin{array}{l}\text { - Terdapat beberapa soal yang kunci jawabannya tidak sesuai } \\
\text { - Soal tidak sesuai indikator } \\
\text { - Stimulus yang tidak berfungsi sebaiknya dihapus }\end{array}$ \\
\hline
\end{tabular}

Sumber: Data Diolah Peneliti (2020)

Setelah ditelaah oleh beberapa ahli, LKPD direvisi berdasarkan hasil telaah dari validator. LKPD yang dikembangkan terdiri dari sampul, kata pengantar, daftar isi, petunjuk penggunaan LKPD, KI dan KD, materi, lembar tugas,latihan soal, dan daftar pustaka. Pada LKPD yang dikembangkan terdapat banyak gambar yang berwarna guna menarik minat peserta didik dan meningkatkan pemahamannya terhadap materi. Selain itu kegiatan atau tugas ditampilkan di awal LKPD sebelum masuk pada materi untuk mendorong peserta didik turut aktif dalam pembelajaran.

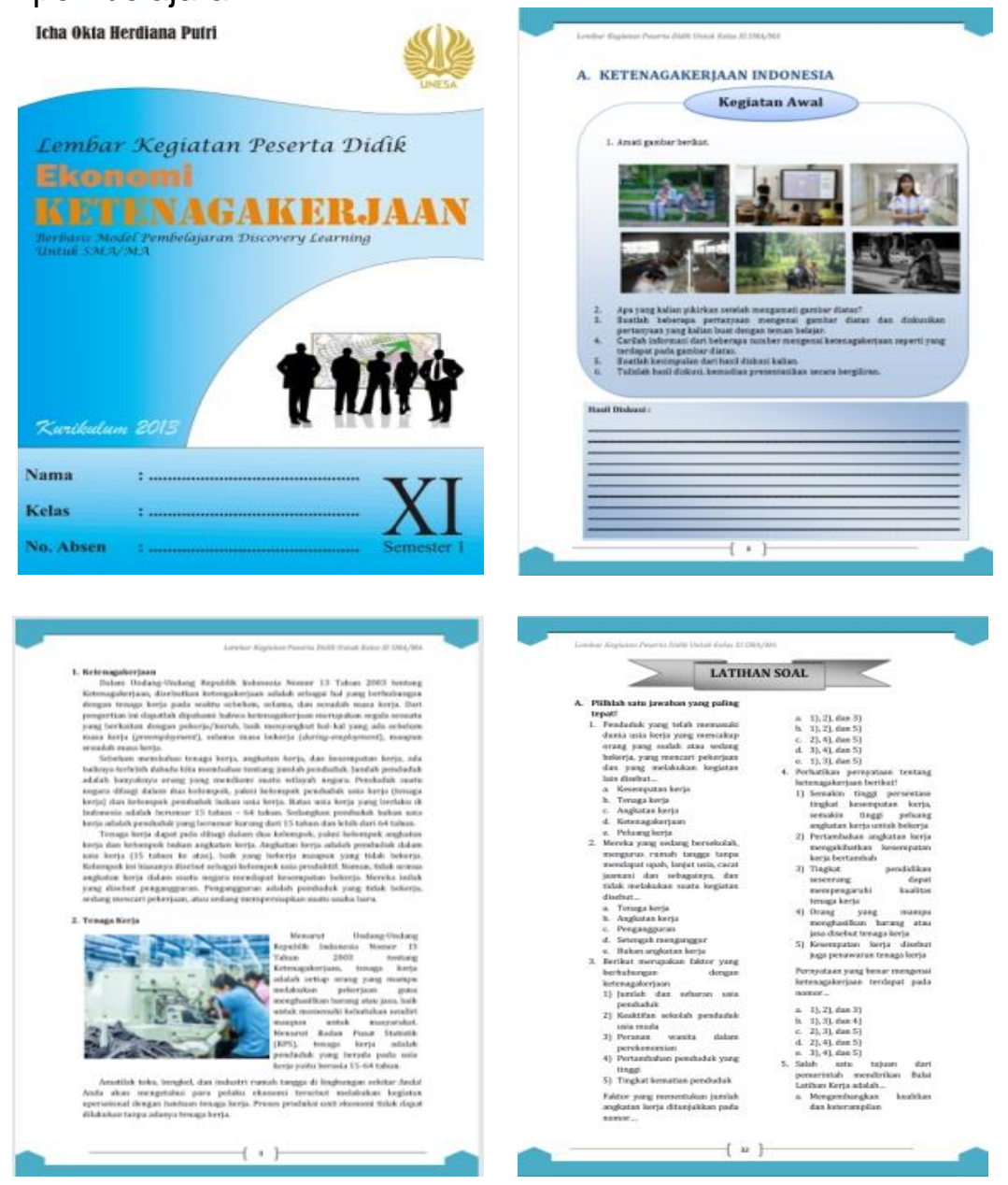

Gambar 5. LKPD Setelah Revisi 
Selesai direvisi selanjutnya LKPD divalidasi oleh validator. Validasi dilaksanakan untuk mengukur kelayakan LKPD berbasis model pembelajaran discovery learning. Berikut tabel rata-rata hasil validasi:

Tabel 8. Rata-rata Hasil Validasi Para Ahli

\begin{tabular}{|c|l|c|c|}
\hline No. & \multicolumn{1}{|c|}{ Validator } & Skor & Keterangan \\
\hline 1. & Ahli Materi & $84,8 \%$ & Sangat Layak \\
\hline 2. & Ahli Pembelajaran & $75 \%$ & Layak \\
\hline 3. & Ahli Kegrafikan & $77,14 \%$ & Layak \\
\hline 4. & Ahli Evaluasi & $99,73 \%$ & Sangat Layak \\
\hline \multicolumn{2}{|l}{ Rata-rataa } & $\mathbf{8 4 , 1 6 \%}$ & Sangat Layak \\
\hline
\end{tabular}

Sumber : Data diolah peneliti (2020)

Setelah dinyatakan layak oleh para ahli, LKPD diuji cobakan ke peserta didik kelas XI SMAN 1 Cerme sejumlah 36 peseerta didik. Ujicoba lapangan dilakukan dengan memberikan LKPD untuk peserta didik. Kemudian peseerta didik diarahkan untuk membaca, mendalami, dan mencoba menyelesaikan tugas dan soal pada LKPD melalui via online dikarenakan kondisi yang tidak memungkinkan untuk dilakukan dengan tatap muka secara langsung. Kemudian peserta didik diberikan angket untuk melihat kepraktisan LKPD berdasarkan respon dari peserta didik. Hasil respon peserta didik mendapat rata-rata sebanyak $89,16 \%$ dan dikategorikan ke dalam kriteria sangat layak.

Untuk mengukur keefektifan LKPD melalui hasil perbandingan hasil pretest dan posttest. Pretest dibeagikan pada peserta didik sebelum LKPD dibagikan, dan posttest dibagikan selesai LKPD dibagikan dan digunakan oleh peserta didik. Untuk soal pretest dan posttest yang diberikan berupa soal pilihan ganda yang tergolong level kognitif $\mathrm{C} 1$ sampai C6. Pretest dan posttest juga dilakukan secara online karena karena suasana yang tidak memungkinkan untuk dilakukan secara tatap muka secara langsung. Dari hasil pretest dan posttest mendapat skor rata-rata $\mathrm{N}$-gain sebanyak 0,72 dan dikategorikan kedalam kriteria sangat layak.

\section{Pembahasan}

1. Kelayakan LKPD Berbasis Model Pembelajaran Discovery learning

Kelayakan LKPD berbasis model pembelajaran discovery learining diukur dari hasil validator diantaranya ahli materi, kegrafikan, pembelajaran, dan evaluasi. Sesuai pernyataan dari Riduwan (2016) bahwa kriteria kelayakan LKPD dikatakan layak apabila memperoleh presentase lebih dari 61\%Data deskriptif kuantitatif merupakan hasil yang didapat dari hasil validasi. Data yang dihasilkan berupa angka yang dianalisis kedalam bentuk kalimat.

Pertama, validasi ahli materi mendapatkan rata-rata sebanyak $84,8 \%$ tergolong pada kriteria sangat layak. Hal ini berarti bahwa komponen pada materi LKPD memenuhi kriteria kelayakan karena memperoleh skor persentase lebih dari $61 \%$.

Kedua, hasil validasi ahli pembelajaran memproleh persentase rata-rata sebanyak $75 \%$ termasuk kedalam kriteria layak. Hal ini menyatakan bahwa komponen pada pembelajaran yang ada pada LKPD memenuhi kriteria kelayakan karena memperoleh skor persentase lebih dari $61 \%$.

Ketiga, validasi ahli kegrafikan mendapatkan hasil persentase rata-rata sebesar $77,14 \%$ yang termasuk kedalam kriteria layak. Hal ini dapat diartikan bahwa komponen kegrafikan yang terdapat pada memenuhi kriteria kelayakan karena memperoleh skor persentase lebih dari $61 \%$.

Keempat, validasi ahli evaluasi mendapatkan hasil persentase rata-rata sebesar $99,73 \%$ tergolong pada kriteria sangat layak. Hal ini menyatakan kalau komponen evaluasi yang ada pada LKPD memenuhi kriteria kelayakan karena memperoleh skor persentase lebih dari $61 \%$

Dari keempat ahli tersebut diperoleh rata-rata sebesar $84,16 \%$. Hal ini menyatakan kalau LKPD yang dikembangkan layak dijadikan sebagai bahan ajar ekonomi. Sesuai dengan penelitian Mutia, Kasrina, \& Ariefa (2019) bahwa pengembangan LKPD dengan 
model discovery learning layak dijadikan sebagai bahan ajar dikelas dimana pada penelitian ini memperoleh hasil validasi para ahli sebesar $85,5 \%$.

\section{Kepraktisan LKPD Berbasis Model Pembelajaran Discovery learning}

Kepraktisan LKPD berbasis model pembelajaran discovery learning diukur dari respon peserta didik. Sesuai dengan pendapat dari Ahmadi (2009) bahwa respon merupakan hasil yang diperoleh seseorang dari kegiatan mengamati suatu hal yang tersimpan dalam ingatannya. Berdasarkan data angket respon peserta ddik memperoleh hasil rata-rata sebanyak $89,16 \%$ dan termasuk kriteria sangat layak dengan rincian sebagai berikut: pada komponen materi memperoleh hasil sebesar 90,27\%; untuk komponen penyajian memperoleh hasil sebesar $87,03 \%$; sedangkan pada komponen bahasa mendapatkan hasil sebanyak 93,05\%; dan pada komponen kegrafikan mendapatkan hasil sebanyak $87,96 \%$. Hasil tersebut membuktikan kalau LKPD yang dkembangkan memiliki manfaat bagi peserta didik untuk menambah informasi peserta didik pada materi ketenagakerjaan. Serta mendorong minat peserta didik untuk dapat meningkatkan hasil belajarnya serta praktis digunakan sebagai bahan ajar karena memperoleh persentase lebih dari $61 \%$.

Hal ini sesuai dengan penelitian dari Sannah, Kadaritna, \& Tania (2015) bahwa penggunaan LKPD dengan model discovery learning praktis digunakan sebagai bahan ajar dikelas dimana dalam penelitian memperoleh hasil penilain respon peserta didik pada aspek ketebacaan sebanyak $87,62 \%$ dan aspek kemenarkan sebanyak $86,05 \%$. Selain itu, penelitian dari Juliyanto (2017) juga membuktikan bahwa penggunaan LKPD dengan model discovery learning praktis digunakan guru untuk menunjang pembelajaran dimana hasil dari respon peserta didik mendapat rata-rata persentase sebanyak $87 \%$.

\section{Efektifitas penggunaan LKPD Berbasis Model Pembelajaran Discovery learning}

Keefektifan LKPD berbasis model pembelajaran discovery learning dapat diukur dari hasil belajar peserta didik. Sesuai dengan pendapat dari Hamalik (2017) bahwa hasil belajar merupakan pengukuran yang dinilai dari bentuk sikap, pengetahuan, dan juga keterampilan dari hasil transformasi seseorang yang dapat diamati. Peningkatan hasil belajar dilihat dari hasil pretest dan posttest. Hasil pretest mendapat persentase sebanyak $61,25 \%$ dan hasil posttest mendapatkan persentase sebanyak $89,44 \%$. Sehingga $n$-gain yang diapat sebanyak 0,72 , hal ini berarti bahwa nilai gain termasuk ke dalam kriteria tinggi. Dari hasil n-gain tersebut mebuktikan hasil belajar peserta didik mengalami peningkatkan tinggi. Maka penggunaan LKPD mampu dikatakan layak dan efektiif untuk digunakan sebagai bahan ajar.

Sesuai dengan penelitian dari Resti, Nina, \& Lisa (2015) bahwa penggunaan LKPD dengan model disovery learning mampu memperbaiki hasil belajar peserta didik di materi teori atom mekanika kuantum. Selain itu, penelitian dari Purwatiningsih (2013) juga terbukti penggunaan LKPD berbasis discovery learning mampu menaikkan hasil belajar peserta didik pada materi fungi yang dibuktikan dengan mendapatkan ketuntasan klasikal yang tinggi.

\section{PENUTUP}

Tujuan dari peneltian ini untuk mengembangkan LKPD berbasis model pembelajaran discovery learning pada materi ketenagakerjaan yang mendapatkan penilaian kelayakan dari para validator dan mendapatkan respon dari peserta didik. Hasil dari penelitian yang didapatkan peneliti dapat menarik kesimpulan yakni: 1) kelayakan LKPD berbasis model pembelajaran discovery learning pada materi ketenagakerjaan memenuhi kriteria kelulusan validasi karena memperoleh hasil rata-rata sebesar $84,16 \%$, dengan rincian hasil validasi ahli materi menerima persentase sebanyak $84,8 \%$ tergolong dalam kriteria sangat layak, untuk hasil validasi ahli pembelajaran mendapatkan hasil sebanyak $75 \%$ tergolong kedalam kriteria layak, sementara untuk hasil validasi ahli kegrafikan menerima persentase sebanyak $77,14 \%$ tergolong pada kriteria layak, serta hasil validasi ahli evaluasi mendapat persentase 
sebanyak 99,73\% tergolong pada kriteria sangat layak; 2) penilaian kepraktisan LKPD berbasis model pembelajaran discovery learning pada materi ketenagakerjaan yang diukur melalui respon peserta didik mendapat persentasee sebesar $89,16 \%$ dan dikategorikan ke dalam kriteria sangat layak; 3) keefektifan penggunaan LKPD berbasis model pembelajaran discovery learning pada materi ketenagakerjaan diukur dari hasil belajar peserta ddik. Dimana hasil belajar peserta didik dilihat dari peningkatan hasil pretest dan posttest. Hasil pretest dan posttest memperoleh $\mathrm{N}$-gain sebanyak 0,72 yang termasuk kedalam kriteria tinggi. Hal ini berarti hasil belajar peserta didik mengalami kenaikan tinggi dan LKPD berbasis model pembelajaran discovery learning efektif dibuat untuk bahan ajar.

Dari kesimpulan tersebut, dapat dikemukakan beberapa saran yakni: 1) LKPD berbasis model pembelajaran discovery learning dapat dibuat guru untuk bahan ajar dikelas karena sudah memenuhi kriteria layak, praktis, dan juga efektif; 2) untuk peneliti berikutnya yang akan melaksanakan penelitian pengembangan LKPD berbasis model pembelajaran disovery learning dan menggunakan 4-D sebagai model pengembangannya disarankan untuk melakukan semua tahapan dari model pengembangan 4D agar memperoleh hasil penelitian yang lebih lengkap; dan 3) LKPD berbasis model pembelajaran discovery learning ini hanya terbatas pada satu materi yaitu ketenagkerjaan, maka disarankan bagi peneliti selanjutnya untuk mengembangkan pada materi lainnya.

\section{DAFTAR PUSTAKA}

Abdurahhman, M. (1999). Pendidikan Bagi Anak Berkesulitan Belajar. Jakarta: PT Rieka Cipta.

Ahmadi, A. (2009). Psikologi Umum. Jakarta: Rieka Cipta.

Astra, I. M., Nasbey, H., Muharrahmah, N. D. (2015). Development of Student Worksheet by Using Discovery Learning Approach for Senior High School Student. Journal of Educational in Muslim Society, 2(2442-9848), 91-96.

Cahyo, A. N. (2013). Panduan Aplikasi Teori-Teori Belajar Mengajar. Yogyakarta: Diva Press.

Fadliana, H., Redjeki, T. \& Nuhayati, D. (2013). Studi Komparasi Penggunaan Metode Pembelajaran Problem Based Learning (PBL) Dlengkapi dengan Macromedia Flash dan LKS Terhadap Prestasi Belajar di Tinjau dari Motivasi Belajar Peserta didik MAteri Asam Basa dan Garam kelas VII SMP Negeri 1 Jaten Karanganyar. Jurnal Pendidikan Kimia.

Hamalik, O. (2007). Proses Belajar Mengajar. Jakarta: Bumi Aksara.

Herman \& Salim. (2015). Pengembangan LKPD Tekanan Hidrostatik Berbasis Keterampilan Proses Sains. Jurnal Sains dan Pendidikan Kimia, 2, 120-131.

Hosnan. (2014). Pendekatan Scientific dan Kontekstual dalam Pembelajaran Abad 21. Bogor: Ghalia Indonesia.

Juliyanto, A. (2017). Pengembangan Lembar Kegiatan Peserta didik (LKS) Berbasis Discovery Learning Pada Kompetensi Dasar Menjelaskan Konsep PDB, PDRB, PNB, dan PN di SMA Sejahtera Surabaya, 5

Kurniasih, I., \& S. B. (2014). Perancangan Pembelajaran Prosedur Pembuatan RPP Sesuai dengan Kurikulum 2013. Jakarta: Kata Pena.

Lestari, I. (2013). Pengembangan Bahan Ajar Berbasis Kompetensi. Padang: Akademia.

Mutia, L., Kasrina, Yani, A. P. (2019). Pengembangan LKPD Model Discovery Learning Berdasarkan Identifikasi Mangrove di TWA Pantai Panjang Bengkulu. Jurnal Pendidikan Dan Pembelajaran Biologi, 3(2598-9669), 59-66.

Nua, M. P., Wahdah, N., \& Mahfud, M. (2018). Pengembangan Lembar Kerja Peserta Didik (LKPD) K-13 Berbasis Dicovery Learning Peserta didik SMA Kelas X Pada Materi Analisis Vektor. Jurnal Nalar Pendidikan, 6(2477-0515), 95-104.

Nurisalfah, R., Ritna, N. K., \& Tania, L. (2015). Pengembngan LKS Menggunakan Model Discovery Learning Pada Materi Teori Atom Mekanika Kuantum. Jurnal Pendidikan Dan Pembelajaran Kimia, 4, 197-208.

Prastowo, A. (2014). Panduan Kreatif Membuat Bahan Ajar Inovatif. Yogyakarta: Diva Press. 
Prastowo, A. (2015). Panduan Kreatif Membuat Bahan Ajar Inovatif Menciptakan Metode Pembelajaran yang Menarik dan Menyenangkan. Yogyakarta: Diva Press.

Prayitno. (2013). Kaidah Keilmuan Pendidikan dalam Belajar dan Pembelajaran Jilid 2. Padang: UNP Press.

Purwatiningsi, S. 2013. Penerapan Metode Penemuan untuk Meningkatkan Hasil Belajar Peserta didik pada Materi Luas Permukaan Dan Volume Balok. Jurnal Elektronika Pendidikan Matematika Tadulako, 1(1), 53-63.

Rahayu, D., \& B. (2018). Pengembangan Lembar Kerja Peserta Didik (LKPD) Berbasis Pemecahan Masalah Matri Bangunan Datar. JPGSD, 6.

Riduwan. (2012). Skala Pengukuran Variabel-Variabel Penelitian. Bandung: Alfabeta.

Rochmad. (2012). Desain Model Pengembangan Perangkat Pembelajaran Matematika. Jurnal Kreano, 3(2086-2334), 59-72.

Sannah, I. N., K. N., \& Tania, L. (2015). Pengembangan LKS Dengan Model Discovery Learning Pada Materi Teori Atom Bohr. Jurnal Pendidikan Dan Pembelajaran Kimia, 4, $184-196$.

Syah. (2004). Psikologi Pendidikan dengan Pendekatan Baru. Bandung: PT Remaja.

Tambunan, N. (2016). Pengaruh Strategi Pembalajaran dan Minat Belajar Terhadap Kemampian Berpikir Kreatif Matematis Peserta didik. Jurnal Formatif (Vol. 3).

Trianto. (2014). Model Pembelajaran Terpadu. Jakarta: Bumi Aksara.

Trianto. (2017). Model Pembelajaran Terpadu Konsep, Strategi Implementasinya dalam Kurikulum Tingkat Satuan Pendidikan (KTSP). Jakarta: PT Bumi Aksara. 